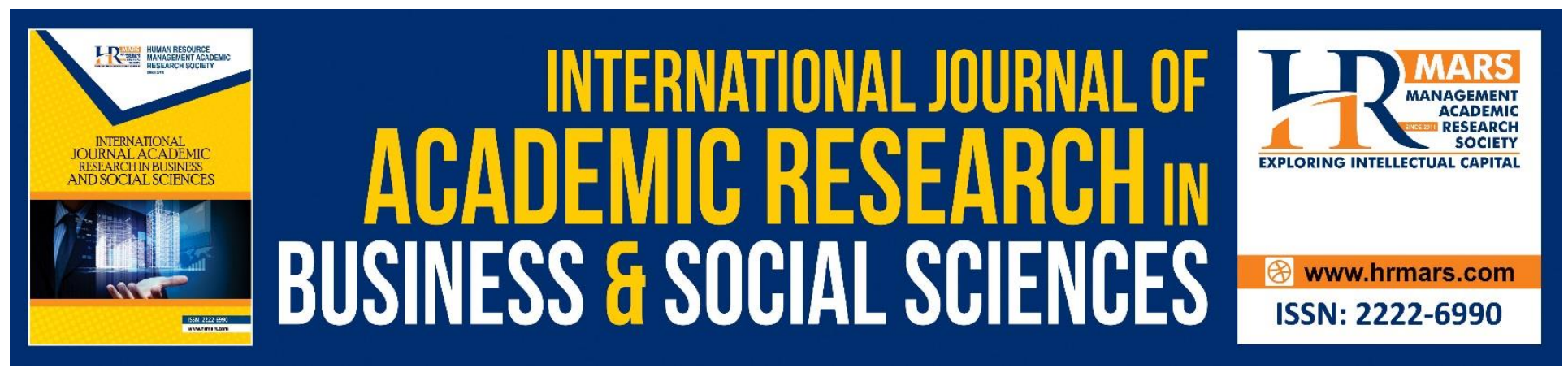

\title{
Constraints Affecting the Increase of Sago Production: A Case of Melanau Rural Youth's Participation in Sago Industry in Sarawak, Malaysia
}

Siti Zanariah Ahmad Ishak, Ahmad Nizar Yaakub, Awang Ideris Awang Daud, Siti Haslina Hussin, Adibah Yusof

To Link this Article: http://dx.doi.org/10.6007/IJARBSS/v11-i14/8529

DOI:10.6007/IJARBSS/v11-i14/8529

Received: 06 November 2020, Revised: 23 December 2020, Accepted: 20 January 2020

Published Online: 21 January 2021

In-Text Citation: (Zanariah et al., 2021)

To Cite this Article: Ishak, S. Z. A., Yaakub, A. N., Daud, A. I. A., Hussin, S. H., \& Yusof, A. (2021). Factors Affecting Brand Relationship Quality of Halal Food and The Mediating Role of Halal Literacy. International Journal of Academic Research in Busines and Social Sciences. 11(14), 51-70.

Copyright: (C) 2021 The Author(s)

Published by Human Resource Management Academic Research Society (www.hrmars.com)

This article is published under the Creative Commons Attribution (CC BY 4.0) license. Anyone may reproduce, distribute, translate and create derivative works of this article (for both commercial and non-commercial purposes), subject to full attribution to the original publication and authors. The full terms of this license may be seen at: http://creativecommons.org/licences/by/4.0/legalcode

Special Issue: Contemporary Business and Humanities Landscape Towards Sustainability, 2021, Pg. 51 - 70 http://hrmars.com/index.php/pages/detail/IJARBSS JOURNAL HOMEPAGE

Full Terms \& Conditions of access and use can be found at http://hrmars.com/index.php/pages/detail/publication-ethics 


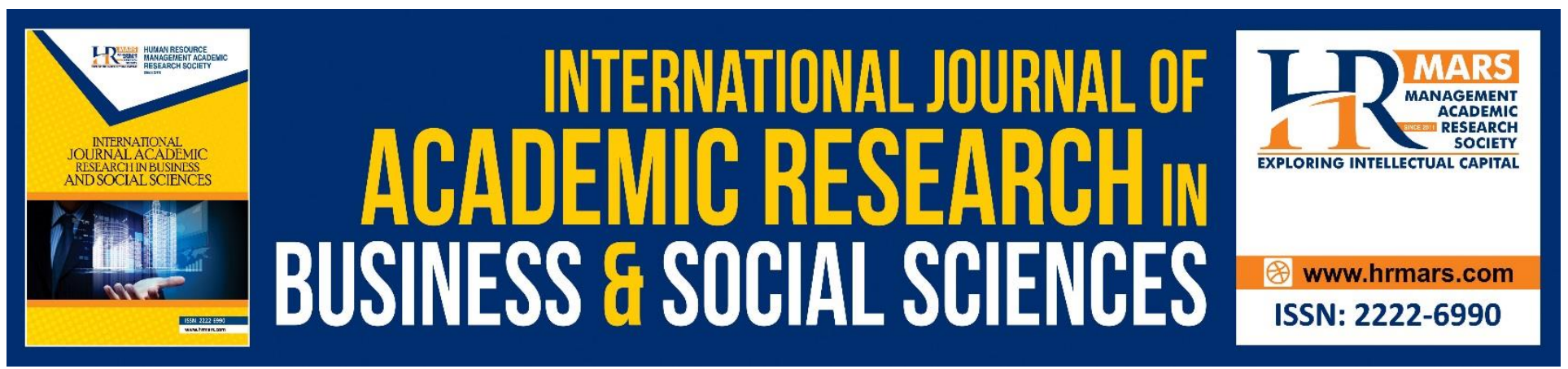

\title{
Constraints Affecting the Increase of Sago Production: A Case of Melanau Rural Youth's Participation in Sago Industry in Sarawak, Malaysia
}

\author{
Siti Zanariah Ahmad Ishak, Ahmad Nizar Yaakub, Awang Ideris \\ Awang Daud, Siti Haslina Hussin, Adibah Yusof
}

Faculty of Social Sciences and Humanities, Universiti Malaysia Sarawak, Kota Samarahan, Sarawak Email: aizana@unimas.my

\begin{abstract}
Sago industry which comprises sago cultivation, processing and sago-based food entrepreneurship has its own youth participation challenges. Consequently, the study aimed at determining constraints factors affecting rural youth sago producers. The constraint factors, namely internal and external factors are developed from modelling reason action theory. Data were collected from 200 youth sago producers in Mukah Division via face-to-face interview using a close-ended questionnaire. The data were analysed by means of descriptive statistics, exploratory factor analysis and binary logistic regression model. The descriptive statistic showed the pattern of youth participation in the sago industry. The result of exploratory factor analysis identified six constraints factors affecting youth sago producers; commodity price, new knowledge, physical infrastructure, income, assistance and training. The result of binary logistic regression showed that the low participation of part-time to fulltime participation of youth sago producers is significantly influenced by new knowledge, physical infrastructure and training constraint factors. The study suggests rural youth requires technological advancement in the sago industry. In addition, the findings may provide useful information to the relevant stakeholders to re-evaluate the assistance and support programs to increase the participation and productivity of the Melanau youth. Furthermore, encouragement be given to more non-Melanaus to participate in sago industry.
\end{abstract}

Keywords: Sago Industry, Youth, Work, New Knowledge, External-Internal Constraints Model, Factor Analysis

\section{Introduction}

Sago palm is an indigenous crop of rural communities in Asia and the Pacific Region. Specifically, rural communities in Indonesia, Papua New Guinea and Malaysia respectively are the main producer of sago commodity. The economic activity of sago has played an essential role in sustaining rural livelihood either for subsistence, trading at the local and domestic market as well as for export. In 
Malaysia, some Melanau community resides in Mukah Division depend on sago as their livelihood. In Indonesia, rural community that associate their livelihood with sago include Luwu community in Luwu Utara Regency, South Sulawesi Province (Trisia, 2017) and Marind and Mandobo tribes in Merauke Regency, Papua (Simatupang, 2019). In Papua New Guinea, Arapesh people of Sepik River Basin consume sago (Toyoda, 2008). Rural youth are involved in different activities of sago production as a continuation of their family work tradition. However, sago farmers and landowners are predominantly rural people of 40 years old and above both in Indonesia (Wardis, 2014) and Malaysia (Yaakub, Mohamad Naim \& Awang Hamdan, 2018). Likewise, in the downstream sector rarely cottage industry of sago-based food products business venture is owned by female youth, instead, it mainly comprising of 40 years old women and above (Taibi, Ishak \& Tuah, 2018).

Constraints factors can be viewed from external and internal perspectives. On the one hand, the external constraints factors refer to the stigmatization of agriculture sector and working condition as the sector is included in the "4Ds" employment category (Ahmad, et. Al., 2018). The 4Ds refer to dirty, dangerous, difficult and demeaning employment where youth avoid these jobs. Furthermore, rural youths have more job options in the service and manufacturing sectors as a result of urbanization. Moreover, education attainment has allowed them to obtain technical and professional jobs. On the other hand, the internal constraints factor refers to the challenges that exist within the specific agriculture sector. The common constraints faced by smallholders are lack of infrastructure, credit access and land ownership. However, innovation in farming method and mechanisation in performing daily tasks as a result of technology advancement in agriculture may slowly change the stigma and ease the working condition.

The Sarawak government envisions more involvement of youths in agriculture sectors. The data in 2018 showed that out of 171,192 farmers registered with Sarawak Area Farmers' Association (PPK), youth comprises 20,543 or a total of $12 \%$ (Utusan Borneo, 2018). Overall, the total number is increasing if compared with the figure in 2017, where the total farmers were 168,000 (Gari, 2017). However, youth have shown interest to involve in more appealing agriculture sectors including pepper, oil palm and honey (kelulut) processing but sidelined sago as the cash crop is not in the top list (Suara Sarawak, 2019). The lack of participation among rural youth the sago industry needs to be studied as it affects the future of this industry. The current ageing of many local sago smallholders and workers in the sago-related cottage industry suggested that rural youth needed to take over the jobs of their parents in the upstream and downstream sectors of the sago industry

The general aim of the paper is to determine the constraint factors of youth sago producers' participation in the sago industry. The factors are investigated based on the internal and external environment of the sago industry. The objectives of the paper are, to study the constraint factors of youth productivity in the industry, and to determine the effect of constraint factors on youth participation in the industry.

\section{Literature Review}

Constraints and Work in Sago Industry 
This section discusses the external constraint factors. The factors are derived from stakeholders' effect of sago industry management on youth involvement.

Mukah Division Sago producers are those who participate in two sectors of economic activity, namely upstream and downstream of the sago industry. The upstream sector consists mainly of smallholders and members of their family including their wives involved in growing, harvesting and selling the crop to the mills. There are also middlemen who have leased the sago trees from farmers. Smallholders refer to the farm operation, which is dependent on family members (Toader \& Roman, 2015). Currently, Sarawak's Melanau youths have been involved in farm works that have been passed down from their family over many generations. During weekends and school holidays, early teenagers and teenagers who are still in school will help their parents on the farm or engage in odd jobs at other farms. Sago smallholder's family receive various assistances and supports from various government bodies (Borneo Post Online, 2018).

The challenge of the upstream sector is transporting sago boles outside of the orchard. Apart from the farmers who owned and worked on the land, some labourers work as a sago harvester to fell the tree and push the cut logs from the inland orchard to the river or roadside. Then the logs are floated in the river, or transported to sago mills by lorry. Some orchards are further inland, making the production of logs increasingly difficult as well as the soft peat soil makes it difficult to push the cut logs.

The challenge of the downstream sector is on the unsatisfactory sago price for sago bole as compared with its production price. The sago mill is privately owned by individuals in the downstream sector, and it provides youth employment. This company is purely a private business where the operation. There was a government agency attempt in the past to build a mill for sago processing, but it was only short-lived. The sago pith is transformed into sago flour by six mills in Dalat and two mills in Mukah. A Sago Board is proposed to the authority as a mechanism for providing the smallholders with a decent commodity price of sago boles (Naim, Yaakub, Hamdan, 2016). The mill converts the logs into sago starch, and the commodity is finally ready for export and sale to retailers.

Finally, there is the sago entrepreneurship in downstream work and employment, where they use sago starch to produce and sell varieties of traditional food for commercial use. Various federal and state ministries generously provide funds, equipment, advice, and training to assist women entrepreneurs across the country (Ming \& Siong, 2014). Women use sago flour to make sago pellets as a traditional staple food for the Melanau community in the cottage industry (Taibi, Ishak, \& Tuah, 2017). Other women make local biscuits, tebaloi which promote indigenous ethnic Melanau food for tourism purposes. Women also sell biscuits and cake at the local market that are made from sago flour. Besides, sago producers could be involved in both the upstream and downstream sectors; they can be farmers, and they are also sago-food entrepreneurs.

Table 1 showed that the sago cultivation is occupied by 46,768 hectares of smallholders ' land and a small number of mini estate of 4,750 hectares with total 51,518 hectares in 2017. These figures did not achieve the targeted plan that had been set up in 2006. According to the Mukah Division 's Strategic Development Plan 2006 - 2010, it supposedly had 53,538 hectares of sago area targeted by 
the end of the 9th Malaysian Plan in 2010, (Rakan Sarawak, 2006; Forouhari et al., 2019). Furthermore, the estate plantation scheme established in 1987 that targeted 250,000 hectares of sago plantation by the end of 2020 was also far from the goal (Borneo Post, 2014).

\begin{tabular}{|l|c|c|c|}
\hline & Matured (Ha) & Immature (Ha) & Total (Ha) \\
\hline Small Holder & 28,110 & 18,658 & 46,768 \\
\hline Mini Estate & 1,220 & 3,530 & 4,750 \\
\hline Grand Total & 29,330 & 22,188 & 51,518 \\
\hline
\end{tabular}

Source: Sago starch 10 years performance (2017)

Table 1: Sago Cultivation Area in 2017

Sago starch has high demand but the supply is limited (Borneo Post Online, 2018). Indonesia also experiences low production as opposed to the large area of the available sago palm tree (Ahmad, 2014). Sago starch production in Sarawak has stagnated for the past 20 years although the total area of cultivation is increasing (Edgar, 2019). Sago starch has increasingly found commercial values in food and non-food industries as well as being a traditional staple food for certain indigenous communities. Sago flour is ranked $4^{\text {th }}$ as an export commodity that contributes to Sarawak revenue of industrial crops after palm oil, pepper and cocoa (Chew et al., 2012). In 2017, Sarawak's export volume for sago starch was $40,885 \mathrm{mt}$ valued at RM86.6 million where approximately $52 \%$ is exported to Peninsular Malaysia, 33\% to Japan and the rest is to other countries as well as for domestic consumption (Borneo Post Online, 2018). According to a report, Malaysia also imports sago starch from Thailand for the country's consumption (BFRO, n.d) to fulfil the higher demand of the flour in Peninsular Malaysia.

\section{Youth Involvement}

This section discusses the internal constraints that fall within the categories of socioeconomic, cultural and behaviour. These categories shape the perception of individuals on their industry involvement.

Sago is produced uniquely by the people of Melanau and the source of labor comes mainly from the region. Melanau youth have been exposed and engaged in economic sago activities since they were young, depending on the type of sago sectors that their family are involved in. Mukah Division Sago starch had been traded to Singapore and Brunei since the 1800s. Sago trees are considered savings for Melanau smallholders where they can harvest the trees whenever they are short of large amounts of cash for important occasions (Ishak, Taibi \& Yaakub 2017). On a positive note, the norm provides them with a sense of economic stability. Moreover, smallholders who lease the sago tree will get the cash whenever they need from the middleman. On the other hand, the norm plus the laid-back rural lifestyle may contribute to a placid attitude towards the motivation in increasing their participants. Additionally, the practice may contribute to the inappropriate time of sago harvesting that leads to low starch extraction. 
Young people have a diverse choice of jobs and some of the incentives offer better income. Studies in Malaysia and other developing countries found that youth expects a better salary from the agricultural sector for them to participate in the agriculture sector. A study conducted among rural youth who live in oil palm resettlement. They willing to work in oil palm employment provided the wages are better (Abdullah, Ahmad, Ayob, 2016). Rural youth determinants to participate in agriculture is Abia State Nigeria is also depended on wage (Agwu, Nwankwo and Anyanwu, 2012). Mukah Division is situated at the strategic location of rich natural resources including its coal-mining and logging areas in the neighbouring Sibu Division. The Mukah Division's main cash crop, which is oil palm, also competes with the sago industry in attracting young Melanau to work in the oil palm industry., the Mukah Division also has colleges and pre-university education that allow young people to pursue technical and professional jobs. Eventually, since 2008, there has been rapid urbanization where Mukah Division is partly developed under the development schemes of the Sarawak Corridor of Renewable Energy (SCORE). The project is planned to make rural areas more open to economic development as well as to provide young people with job opportunities including in manufacturing.

The physical characteristics of the sago palm and cultural practice effects either part-time or full time mode of work of sago farmers. The maturity period of sago palms where it takes 10 - 12 years to be harvested is one reason to make sago cultivation as part - time work. The practise of having two or more jobs is termed as pluriactivity where farmers earn supplementary income from doing nonfarm work when they did not earn enough from farming work (Bessant, 2006). In terms of cultural practice, some smallholders in Indonesia still treat sago cultivation as traditional part-time jobs attending semi-wild tree. (Ahmad, 2014) Consequently, if they don't practice systematic farming, either full-time or part-time smallholders may experience low yield.

There are differences between full - time and part-time operators in terms of work efficiency and motivation. A study found that there is a different farm yield between part - time and full-time farmers where the latter display lower yield (Singh \& Williamson, 1981) regarding their farm yield. Therefore, the mode of work is studied in relation to motivation for work. Uddin et al. (2014) compare motivating factors between university students working as part - time employees and full - time employees of Chittagong organizations. The study found that the motivation factors for full - time employees are decent pay, job security and good working conditions. While the motivation factors of the part - time employees are job flexibility, interesting work and a good salary. The difference between the two types is that the first motivation of the full - timers is based on intrinsic factor while the first motivation factors of the part - timers are based on extrinsic factor.

Other critical factors identified in the literature regarding participation in the new millennia's agricultural sector include mechanization, new technology, and training. The Agriculture Entrepreneurship Training Program, which focuses on technology transfer by the Malaysian Agricultural Research and Development Institute, reports good response and promising participants (Khulidin, 2015). University students view the practice of urban agriculture that makes use of technology positively (Tiraieyari \& Krauss, 2018). 


\section{Model}

The present study's larger research project investigates the young people's intention to increase their participation in the sago industry. The two main components of Reasoned Action Theory, attitudes and subjective norms (Ajzen \& Fishbain 1980) are applied as an umbrella model to measure the sago producers' intention. Whilst this sub-research studies constraints factors that serve as the component of disablers of youth participation that limit their involvement in the sago industry (see Figure 1). The constraints factors are developed along the line of subjective norms and attitude paradigm which in the broad layman's term is internal and external factors. Consequently, this study proposes separate survey instrument focusing on constraints factors. Other researches, however, do not separate the negative (constraints) and determinants factors. Nag, Jha, Mohamad \& Maiti (2017) developed research instruments that measure rural youths' attitude towards dairying occupation which comprise positive and negative statements of the occupation. Other research that uses a variety of terms similar to constraints including barriers, limitations and challenges. Additionally, Afande, Maina \& Maina (2015) conceptualised constraints in agriculture sectors into few attitudes that come from the psychological state of individuals including disinterest, doubt and negative perception. These attitudes are called endogenous factors. Meanwhile, the exogenous factors apply to the individual's external factors.

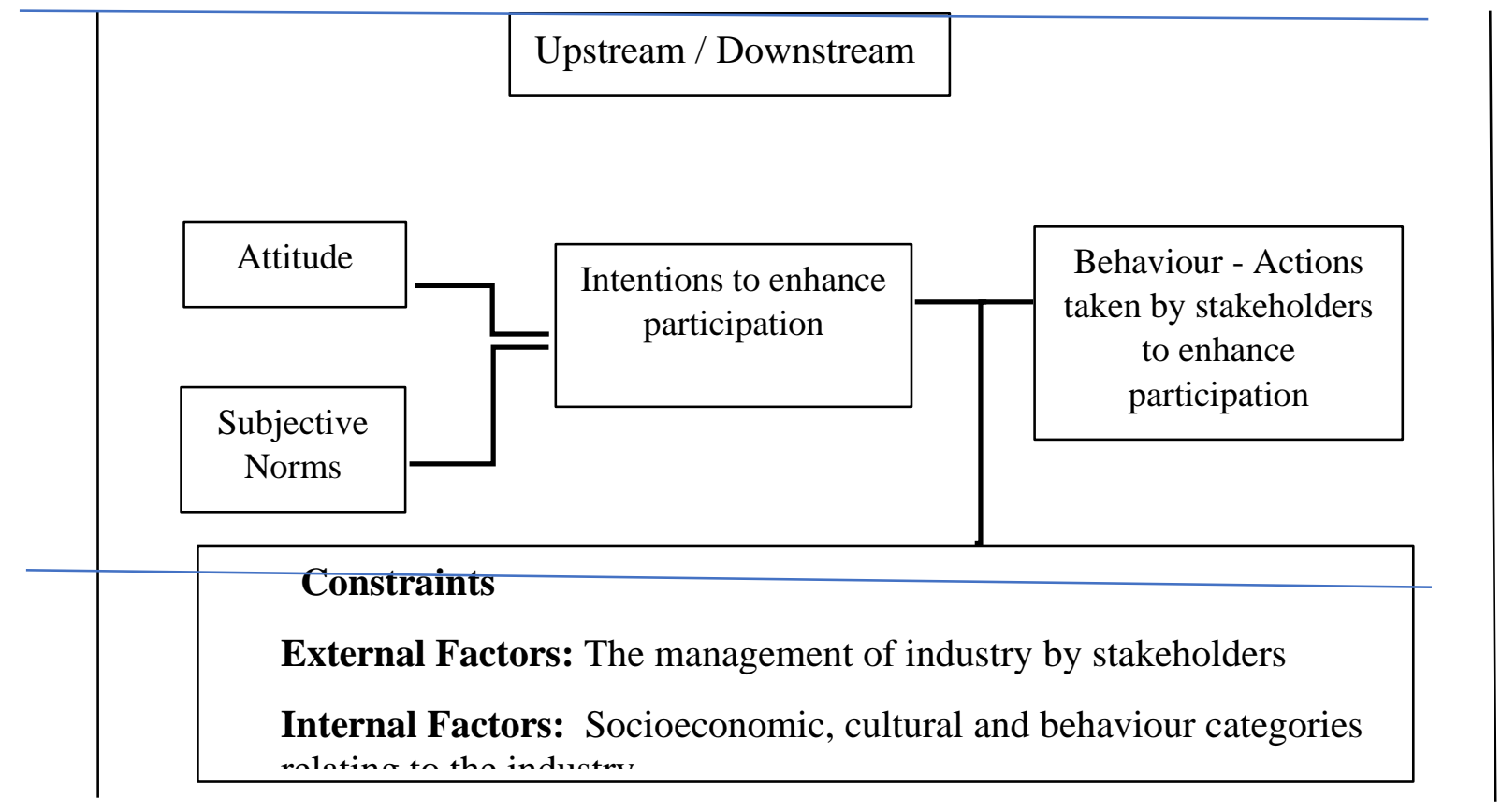

Figure 1: Model adapted from Ajzen and Fishbain (1980)

\section{Method}

A quantitative research method is used in this study. For data collection, the survey questionnaire is used to gather the data. The survey was carried out among youth population in three main sago producer districts of Mukah Division. Mukah city centre is approximately 461 kilometers from Kuching, the capital city of Sarawak. The population of Melanau is concentrated in the Mukah division 
that includes Mukah, Dalat and Daro area and the total population in 2010 is 110,024 (The Official Portal of Sarawak Government, n.d). Youth sample is developed based on their numerous ways of involvement in sago industry; from youth that help the family during the school holiday to youth that works full-time in the industry. Stratified random sampling involves dividing the entire youth population into homogeneous groups called strata. Random samples are then selected from each district to represent the youth population of Mukah. In the case of this study, the number of questionnaires distributed to the youth is determined by the number of areas planted with sago (Dalat 28,169 ha; Mukah 6,472 ha; Matu 4,520 ha and Daro 3,149 ha. (Department of Agriculture of Malaysia, Industrial Crop Statistics Malaysia, 2014). Guided by a specific selection criteria of participants, that is the youths who are actively participating in the sago industry, thus, a total of 200 youths are purposely surveyed. Specifically, out of 200 questionnaires, 100 of them were administered in Dalat, 50 in Mukah and, 25 each for Matu and Daro.

This study is part of a research that includes five main components including one component of constraint factors. A total of 39 statements were prepared to capture factors affecting sago production and respondents were asked to rate their attitude using the five - point Likert scale towards constraints, where 1 is no constraints and 5 is the highest constraints. The validity of the instrument is established where each question is developed on the basis of the researcher's and members ' objective of study and expertise in this research group as most of them had been intensively involved in past socio - economic research sago. The next step is conducting a pilot study, and the outcome is used to refine the final data collection questionnaire. Finally, data collection is carried out with the help of a local research assistant, who is familiar with Melanau people's language and tradition in the Mukah Division.

Firstly, the data is analysed using Statistical Package for Social Science (SPSS) software version 25. Descriptive analysis namely frequencies and percentages were used to describe the sociodemographic characteristics of the respondents in sago industry.

Second, exploratory factor analysis using the principle factor model with varimax rotation was used to determine major dimensions from a wide range of items developed to capture constraints that limit youth participation in the sago industry to better understand the data. Furthermore, varimax rotation method makes the output reliable and Eigenvalues that indicate number $>1$ is a reliable value of factor extracted. The technique aims to develop some dimensions of constraints factors. Keiser-Meyer Olkin (KMO) determines the adequacy of the sampling, and 0.6 or higher is considered a meaningful value for factor analysis. Additionally, Bartlett's sphericity test evaluated the hypothesis that the matrix of correlation is an identity matrix that means the items are uncorrelated. The test value $(p<0.05)$ is appropriate for an analysis of the factor.

Finally, in this section, logistic regression was employed to predict the models for the participation mode of youth in the sago industry with six constraints variables. The dependent variables were the binary variable, part-time and full-time mode of work. Logistic regression allows dichotomous variables or qualitative response. In addition, this statistical analysis could be used to describe the relationship between several independent variables (six constraints factors). Youth participation is 
measured as an interval scale and the independent ones in ordinal scale. The analysis of logistic regression has been applied on part-time and full-time work (Bartoll, Cortès, Artazcoz, 2014) and willingness to plant sago palm (Trisia, 2017). The binary dependent variables were coded with a value of "part-time" $=0$ and "full-time" $=1$. The Goodness of fit of the model was evaluated using HosmerLemeshow test which was greater than 5 percent level indicating that the mode of youth participation could be explained by the model.

\section{Results and Discussion}

Descriptive statistics of frequency and percentages in Table 1 presents a socio-demographic profile of rural youth sago producers ( $N=200)$. The largest age group is between $15-20(43.5 \%), 21-24(28.5 \%)$ and $25-30$ (28\%). More male youth respondents compared to female youth (63 to $37 \%$ ). Respondents who have no formal education (0.5\%), primary (24.5\%), secondary (52\%), pre-university (18.5\%) and tertiary (4.5\%). Many sago producers of the Melanau community engages in both full-time and parttime jobs. The breakdown of the full time job category of the respondents $(\mathrm{N}=200)$ are as follows; schooling (28\%), private sectors, including downstream sago jobs (26\%); not working full time (25\%) public service (10\%), sago upstream jobs (8.5\%) and self-employed, including downstream jobs (7.5). Whilst, the part-time job category of the respondents $(\mathrm{N}=200)$ are as follows; not working as parttimers $(52.5 \%)$, involved in upstream sago (35\%), involved in private sectors, including working in downstream sago (8\%) and self-employed, include working in downstream sago (4.5\%).

Youth's monthly income is as follows; No income (41\%=82), below RM500 $(16.5 \%=33)$, RM501RM1050 (23\%=46) and RM1051-RM1500 (14\%=28). This indicates that many respondents in this category are dependent on their parents or they are only given a small token whenever they help their parents. In the upstream sector, youth who owned land $(1 \%=2)$. The insignificant percentage showed that most of the youth aged 30 and below do not possess the land. They may work as farmers or sago harvester in the family orchard and leased land.

\begin{tabular}{|c|c|c|}
\hline Variables & Frequency (N200) & Percentage \\
\hline Age & & 43.5 \\
\hline 15 to 20 year-old & 87 & 28.5 \\
\hline 21 to 24 year-old & 57 & 28 \\
\hline 25 to 30 year old & 56 & \\
\hline Gender & & 63 \\
\hline Male & 126 & 37 \\
\hline Female & 74 & \\
\hline
\end{tabular}


INTERNATIONAL JOURNAL OF ACADEMIC RESEARCH IN BUSINESS AND SOCIAL SCIENCES

Vol. 11, No. 14, Contemporary Business and Humanities Landscape Towards Sustainability. 2021, E-ISSN: 2222-6990 @ 2021 HRMARS

\begin{tabular}{|c|c|c|}
\hline Education Level & & \\
\hline No education & 1 & 0.5 \\
\hline Primary & 49 & 24.5 \\
\hline Secondary & 104 & 52 \\
\hline Pre-Uni & 37 & 18.5 \\
\hline Tertiary & 9 & 4.5 \\
\hline \multicolumn{3}{|l|}{ Involvement in sago industry } \\
\hline $\begin{array}{c}\text { Part-time (less than } 40 \text { hours per week) } \\
\text { Upstream and downstream }\end{array}$ & 167 & 83.5 \\
\hline $\begin{array}{c}\text { Fulltime (more than } 41 \text { hours per week) } \\
\text { Upstream and downstream }\end{array}$ & 33 & 16.5 \\
\hline \multicolumn{3}{|l|}{ Marital Status } \\
\hline Single & 158 & 79 \\
\hline Married & 42 & 21 \\
\hline \multicolumn{3}{|l|}{ Income } \\
\hline No income & 82 & 41 \\
\hline below RM500 & 33 & 16.5 \\
\hline RM501-RM1050 & 46 & 23 \\
\hline RM1051-RM1500 & 28 & 14 \\
\hline More than RM1501 & 11 & 5.5 \\
\hline \multicolumn{3}{|l|}{ Land Ownership } \\
\hline Owned land & 2 & 1 \\
\hline
\end{tabular}


INTERNATIONAL JOURNAL OF ACADEMIC RESEARCH IN BUSINESS AND SOCIAL SCIENCES

Vol. 11, No. 14, Contemporary Business and Humanities Landscape Towards Sustainability. 2021, E-ISSN: 2222-6990 @ 2021 HRMARS

No land ownership

198

99

Table 1: Socio-Demographic Profile of Youth Sago Producers

Youth participation in sago industry is determined by numbers of working hours per week. The definition of youths' full-time or part-time employment in the sago industry is determined according to the Sarawak Labour Ordinance. Thus, a youth who works less than 41 hours $(83.5 \%=167)$ is considered as a part-timer and youth who works more than 41 hours $(16.5 \%=33)$ is a full-timer in sago industry. This finding indicates that the sago industry is dominated by youths who work parttime. In terms of the type of economic activity, more than half of youth are involved in upstream sectors $(58 \%=116)$, downstream $(19 \%=38)$ and youth that participated in both sectors $(23 \%=46)$.

\begin{tabular}{|c|c|c|}
\hline Variables & Frequency (N200) & Percentage \\
\hline \multicolumn{3}{|l|}{ Part-time } \\
\hline Less than 10 hours & 90 & 45 \\
\hline $11-20$ hours & 46 & 23 \\
\hline $21-30$ hours & 22 & 11 \\
\hline $31-40$ hours & 9 & 4.5 \\
\hline Total & 167 & 83.5 \\
\hline \multicolumn{3}{|l|}{ Full-time } \\
\hline 41 - 50 hours & 8 & 4 \\
\hline $51-60$ hours & 1 & 0.5 \\
\hline $61-70$ hours & 3 & 1.5 \\
\hline $71-80$ hours & 15 & 7.5 \\
\hline 81 hours and above & 6 & 3 \\
\hline Total & 33 & 16.5 \\
\hline \multicolumn{3}{|l|}{ Type of activity } \\
\hline Upstream & 116 & 58 \\
\hline Downstream & 38 & 19 \\
\hline Both & 46 & 23 \\
\hline
\end{tabular}

Table 2: Working Hours Per Week 
Table 3 showed the required reliability tests of exploratory factor analysis technique used for this study which is to examine the constraints factors that influence youth participation in sago industry. The value of Keiser-Meyer Olkin (KMO) was 0.853 which is greater than 0.6, the minimum requirement. Furthermore, Barlett's test of Sphericity showed significant value at $p<0.000$. The significant value acquired from the test is less than 0.05 , therefore the constraints items are suitable for factor analysis.

\begin{tabular}{|l|c|c|}
\hline $\begin{array}{l}\text { Kaiser-Meyer-Olkin Measure of Sampling } \\
\text { Adequacy. }\end{array}$ & 0.853 & \\
\hline Bartlett's Test of Sphericity & 2470.03 \\
& 0 & \\
\hline Approx. Chi-Square & 276 & \\
\hline df & 0.000 & \\
\hline Sig. & & \\
\hline
\end{tabular}

Table 3: Reliability Test

The result in Table 4 shows 24 items (variables) under six factors that fulfil KMO's criterion in having eigenvalues greater than 1 and are considered significant. The test has reduced the initial items from 38 developed for this study to 24 items. Likewise, initial factors were eight and the test has reduced them to six factors. These factors were renamed (1) Commodity Price (2) New Knowledge (3) Physical Infrastructure (4) Income (5) Assistance (Training). These six factors accumulatively explained $66.873 \%$ of the total variation of the constraints factors influencing youth participation in sago industry where the value is acceptable (UCLA, n.d). Items in the six-factor dimensions had factor loadings from the highest 0.843 to the lowest value, 0.59 .

Factor 1: Commodity Price. This factor explained about $15.609 \%$ of the total variance with eigenvalue of 8.458. The factor comprises six items with the factor loading the highest 0.779 to the lowest 0.617 . Participation in upstream and downstream agriculture sectors are limited by commodity price in many ways including high productivity cost compared to low earnings (Najim, et. al, 2007) and fluctuation of the commodity price (Chuangchid, Wiboonpongse, Sriboonchitta \& Chaiboonsri, 2012).

Factor 2: New Knowledge. This factor explained about $14.57 \%$ of the total variance with eigenvalue of 2.254. The factor comprises six items with the factor loading the highest 0.786 to the lowest 0.603 . The constraints in new knowledge refer to lack of communication and lack of exposure in information, innovation and technology. Participation of youth in upstream and downstream agricultural activities can be enhanced by encouraging the use of technology (Shanjeevika, Indumathy \& Murugan, 2018).

Factor 3: Physical Infrastructure. This factor explained about $10.826 \%$ of total variance with eigenvalue of 1.606. The factor comprises four items with the factor loading the highest 0.741 to the lowest 0.591 . The constraints in physical infrastructure are related to the unsuccessful estate 
plantation program ( 2 items), unsuitability of soil for sago cultivation and the lack of road to transport sago logs.

Factor 4: Income. This factor explained about $10.448 \%$ of total variance with eigenvalue of 1.399 . The factor comprises three items with the factor loading the highest 0.837 to the lowest 0.668 . The constraints in income refer to lack of sufficiency, stability and income comparison. Income is a significant constraint of youth participation in the agriculture sector (Abdullah, Ahmad \& Ayob, 2016).

Factor 5: Assistance. This factor explained about $8.446 \%$ of total variance with eigenvalue of 1.185. The factor comprises three items with the factor loading the highest 0.843 to the lowest 0.59 . The constraints in assistance refer to a lack of financial aid from government and private and the issue of land ownership.

Factor 6: Training. This factor explained about $7.514 \%$ of total variance with eigenvalue of 1.148 . The factor comprises two items with the factor loading the highest 0.781 to the lowest 0.684 . The constraints in training refer to a lack of interest and opportunity to participate in training.

\begin{tabular}{lllrrr}
\hline \multicolumn{8}{c}{ Component } \\
1 & 2 & 3 & 4 & 5 & 6
\end{tabular}

A. COMMODITY PRICE

G6. Presence of middle man

0.779

G7. Sago production cost

0.746

G5. Commodity price

0.743

G8. Non existence of mechanism that control commodity price

G4. Stability of commodity price

G29. Own method to increase production

\section{B. NEW KNOWLEDGE}

G38. Info communicated by related agencies

G37. Use of new equipment

0.709

G36. Improvising methods of work

0.672

G34. Seeking info from agencies about innovation 
G39. Clarity of info from agencies about innovation

0.623

G33. Availability of new knowledge on sago industry

0.603

C. PHYSICAL INFRASTRUCTURE

G17. Output from estate development program SSSED

G14. Soil suitability

G16. To participate in sago estate development program

G19. Availability of road to transport sago logs

D. INCOME

G10. Sufficiency of income from sago

0.837

G9. Stability of income from sago

0.672

G11. Income from sago compare to other income

0.668

\section{E. ASSISTANCE}

G2. Financial aid from the Department of Agriculture

G3. Financial aid from private bodies

G13. Land ownership

F. TRAINING

G25. Interest to participate in training

Eigenvalues

$\%$ of Variance

Cumulative \%
8.458

15.069

2.254

1.606

1.399

1.185

1.148

15.06929 .638

14.57

10.826

10.448

8.446

7.514 


$\begin{array}{lllllll}\text { Cronbach's Alpha } & 0.866 & 0.829 & 0.756 & 0.822 & 0.81 & 0.64\end{array}$

Table 4: Factor Analysis

The Omnibus Tests Model (Table 5) for the logistic regression analysis was statistically significant $\mathrm{X}^{2}$ $(\mathrm{df}=6, \mathrm{~N}=200)=42.913 p<.001$, Cox, and Snell $R^{2}=0.193$ Nagelkerke $\mathrm{R}^{2}=0.326$. The model was $86.5 \%$ accurate in its predictions of youth participant mode and type of activity. In Table 6 Hosmer and Lemeshow test results confirmed that the model was a good fit for data, $X^{2}(d f=8, N=200),=3.732, p$ $=.880$ Coefficients for the model's predictors are presented in Table 6 .

Chi-square df Sig.

\begin{tabular}{llll}
\hline Step & 42.913 & 6 & 0.000 \\
Block & 42.913 & 6 & 0.000 \\
Model & 42.913 & 6 & 0.000
\end{tabular}

Table 5: The Omnibus Test Model

Results in Table 6 showed that three from six constraints factors; new knowledge, physical infrastructure and training variables improve the predictive ability of the model youth participation mode in sago industry $(p<0.05)$. The Exp (B) coefficient represents the odds ratio, or the change in the probability of the criterion variables occurring (youth participation mode), in relation to predictor variables of constraints factors.

\begin{tabular}{|l|c|c|c|c|}
\hline Variables & $\beta$ & S.E. & Significance & $\begin{array}{c}\text { Odds Ratio } \\
{[\text { Exp (B)] }}\end{array}$ \\
\hline Commodity Price & 0.038 & 0.395 & 0.923 & 1.039 \\
\hline New Knowledge & 1.152 & 0.428 & 0.007 & 3.166 \\
\hline Physical Infrastructure & -1.498 & 0.519 & 0.004 & 0.224 \\
\hline Income & -0.042 & 0.379 & 0.913 & 0.959 \\
\hline Assistance & 0.314 & 0.355 & 0.375 & 1.370 \\
\hline Training & -1.277 & 0.289 & 0.000 & 0.279 \\
\hline Constant & 2.388 & 1.559 & 0.126 & 10.887 \\
\hline & & & & \\
\hline Hosmer- Lemeshow test & 3.732 & & & \\
\hline Chi-square & & & & \\
\hline
\end{tabular}


INTERNATIONAL JOURNAL OF ACADEMIC RESEARCH IN BUSINESS AND SOCIAL SCIENCES

Vol. 11, No. 14, Contemporary Business and Humanities Landscape Towards Sustainability. 2021, E-ISSN: 2222-6990 @ 2021 HRMARS

\begin{tabular}{|l|c|l|l|l|}
\hline Significance & 0.880 & & & \\
\hline Cox and Snell $\mathrm{R}^{2}$ & 0.193 & & & \\
\hline Nagelkerke $\mathrm{R}^{2}$ & 0.326 & & & \\
\hline Overall predicted percentage correct & 83.5 & & & \\
\hline
\end{tabular}

Table 6: Logistic Regression Part-Time and Full-Time Mode of Work

As $\operatorname{Exp}(B)$ is 3.166 for perceived constraints of acquiring new knowledge in sago industry, an increase of 1 unit of the constraints is tied to a significant $216.6 \%$ or 2 times $(1-3.166=-2.166)$ decrease in the odds that youth will participate in working full-time. The remaining predictors, physical infrastructure $77.6 \%$ or less than one time $(1-.224=0.776)$ and training $72.1 \%(1-.279=0.721)$ or less than one time decrease in the odds that youth will participate in working full-time respectively.

\section{Discussion}

This study found the participation pattern of rural youth sago producers. They are mainly involved in the upstream sector, followed by engagement in both sectors and, lastly, only in downstream. This study also showed that youth who work in the sago industry are mostly part-timers. It is a unique characteristic that has not been found or studied in other crops such as oil palm, paddy and cocoa. Most literature focuses on youth perception regarding agriculture (Tiraieyari \& Krauss, 2018) and the determinant factor of youth choice of career in plantation (Abdullah, Ahmad \& Ayob (2016). They have worked since a young age by helping their parents as their participation is partly continuing the Melanau culture and family tradition. However, the impact of the part-time modes of work is reported of less yield and land usage is not optimised (Hao, Li \& Zhang, 2013; Singh \& Williamson, 1981).

This study proposed a constraint model comprises internal and external factors which are developed based on the subjective norms and attitude dimensions of the theory of reason action. The theory came from the social psychology field. In this study, the external factor is related to stakeholders and management of industry and the internal factor is the participant's socioeconomic, cultural and behaviour related to the industry. This model suggested that constraints factor is a standalone empirical research topic. On contrary, the literature in agriculture showed that constraints, challenges and determinants factors are commonly embedded in larger empirical research (Tiraieyari \& Krauss, 2018; Nag, et al., 2017; Trisia, Metaragakusuma, Osozawa \& Bai, 2017). Additionally, literature in agriculture also showed that some empirical studies on these factors are free from association to any model or theory (Shanjeevika, Indumathy \& Murugan, 2018; Abdullah, Ahmad \& Ayob, 2016; Agwu, Nwankwo \& Anyanwu, 2014).

The logistic regression showed the significant influence of three out of six constraint factors namely new technology, physical infrastructure and training towards full-time participation of youth sago producer in Mukah Division. Rural youth saw a strong significant of new knowledge that disabled their participants. This result is supported by recent research findings (Shanjeevika, Indumathy \& Murugan, 2018) where the constraints of rural youth farmers in India is due to the lack of technical 
skills and training programmes. Research and development (R\&D) program that focuses on efficient modern agricultural technology was received very well by Malaysia's youth (Khulidin, 2015). In the new millennia where IR 4.0 has been emphasised, youth depends more on technology and cherish the usage of digital technology in both upstream and downstream agriculture sectors (Trendov, Varas \& Meng, 2019). Malaysia has capable agriculture institutions that work for agricultural advances (Borneo Post Online, 2017). However, relevant authorities need to ensure that the availability of technology and training programme focusing on R\&D is communicated efficiently to youth (Man, 2012). Additionally, in the era of ICT, rural youth participation in sago industry not only deter by disablers factors of new knowledge and training but also the basic need which is physical infrastructure continuously poses a challenge to them.

\section{Conclusion and Recommendation}

This study contributed to the fact that the industry is dominated by the Melanau youth that works as part-timers. Only a few youths have made a full commitment in choosing to work full-time in the sago industry. Therefore, it is suggested that relevant authorities may support other ethnics to involve in the sago industry. Since the literature of youth participation in cash crops' work in Malaysia is mostly on oil palm, this study has contributed to the sago literature on youth participation in the sago industry. Furthermore, the exploratory factor analysis found six constraints factors that deter them from increasing their participation. These factors are commodity price, new knowledge, physical infrastructure, income, assistance and training. The study recommends that rural Melanau youth is mainly in need of the technological advancement in the sago industry. Youth's mode of participation in full time is influenced more than three times by constraint factors of new knowledge, and less than one time for both physical infrastructure and training. The need for new technology, physical infrastructure and training relate to a common issue in the rural area. For expansion of this topic for future study, it is suggested to measure the relationship between mode of participation (as work in sago industry is culturally part-time) and productivity in the upstream sector. The sago literature shows that productivity is critical because it does not show much progress and it is not known either more participation leads to higher productivity or not.

\section{Acknowledgement}

The funding for this research project was obtained from Tun Openg Chair, the Centre for Sago Research (CoSAR), Universiti Malaysia Sarawak. Research grant No. F06/TOC/1752/2018.

\section{References}

Abdullah, N., Ahmad, S. A., \& Ayob, M. A. (2016). Labour force participation of rural youth in plantation sector of Northern Peninsular Malaysia. Jurnal Ekonomi Malaysia, 50(2), 83-92. doi.org/10 .17576/ JEM-2016-5002-07

Afande, F. O., Maina, W. N., \& Maina, F. M. P. (2015). Youth engagement in agriculture in Kenya:

Agricultural Economics (IJFAEC), 2(1128-2016-92018), 157-164. Retrieved from: https://ageconsearch.umn.ed u/record/163717/

Agwu, N. M., Nwankwo, E. E., \& Anyanwu, C. I. (2014). Determinants of agricultural labour 
Ahmad, M. (2014). Farmer Empowerment to Increase Productivity of Sago (Metroxylon sago spp) Farming. International Journal on Advanced Science, Engineering, Information Tchnology 4(3). Retrieve from: https://media.neliti.com/media/publications/95035EN-farmer-empowe rment-to-increase-productiv.pdf

Ahmad, N. M., Supaat, D. I., Wook, I., Tagoranao, M. S., \& Rahman, N. A. A. (2018). Malaysians' Reluctance to Work in Local 3D Sectors: A Preliminary Review. TheJournal of Social Sciences Research, (4), 220-230. doi.org/10.32861/jssr.sp4.220.223. Retrieved from: https://ideas.rep ec.org/ a/arp/tjssrr/2018p220-230.html

Ajzen, I., \& Fishbein, M. (1980). Understanding attitudes and predicting social behavior. Englewood Cliffs, NJ: Prentice-Hall.

Bartoll, X., Cortès, I., \& Artazcoz, L. (2014). Full-and part-time work: gender and welfare type differences in European working conditions, job satisfaction, health status, and psychosocial issues. Scandinavian journal of work, environment \& health, 40(4), 370 - 379. doi:10.5271/s jweh.3429.

Bessant, K. C. (2006). A farm household conception of pluriactivity in Canadian agriculture: Motivation, diversification and livelihood. Canadian Review of Sociology/Revue Canadienne de sociologie, 43(1), 51-72. doi: 10.1111/j.1755-618X.2006.tb00854.x.

Borneo Post Online. (2014). Objectives of sago project still not met after 26 years. The Borneo Post Online, Sarawak. Retrieved from: https://www.theborneo post.com/2014/11/11/objectives-of-sago-project-still-not-metafter-26-years/

Borneo Post Online. (2018) Uggah: Government committed to develop sago industry. The Borneo Post Online, Sarawak. Retrieved from https://www.theborneopost.com/2 018/07/19/uggahgovernment-committed-to-developsagoindustry/\#: :text=\%E2\%80\%9CUnder\%20the\%20Sago\%20Development\%20Programme ,rehabilitation\%20of\%20sago\%20small\%20holdings.\&text=The\%20total\%20sago\%20area\%2 Oin,marginal\%20increase\%20over\%20the\%20years.

Business of Forest Products, BFPRO. (n.d): Sago Starch. Retrieved from

Challenges and prospects. Journal of Culture, Society and Development Vol.7. Retrieved from: Challenges_of_Sustainable_Livelihood_among_Smallcale_Sago_Farmers_in_Mukah_District _of_Sarawak

Chuangchid, K., Wiboonpongse, A., Sriboonchitta, S., \& Chaiboonsri, C. (2012). Factors affecting palm oil price based on extremes value approach. International Journal of Marketing Studies, 4(6), 54. doi.org/10.5539/ijms.v4n6p54. cific\%20Studies\%234(2)20pp99-116.pdf

Department of Agriculture Malaysia, DOA. (2014). Industrial Crop Statistics, Malaysia. Retrieved from:http://www.doa.gov.my/index/resources/aktiviti_sumber/sumber_awam/makluat_pe rtanian/perangkaan_tanaman/perangkaan_tnmn_industri_2018.pdf

Edgar, N. (2019). Time to establish Sago Board, Craun Research CEO suggests. Dayak Daily. Retrieved from https://dayakdaily.com/time-to-set-up-sago-board-suggests-craun-research-ceo/

Forouhari, S., Ghaemi, S. Z., Jahromi, B. N., Dehaghani, A. S., \& Parsanezhad, M. E. (2019). A New Method for Diagnosing and Follow up the Treatment of Uterine Fibroids: Uterine Endoscope: a Review Article. International Journal of Academic Research in Business and Social Sciences, 1(1), 14-21. 
Gari, P. (2017) Kerajaan negeri diminta bangunkan PPN. Utusan Borneo, Retrieved from https://www.utusanborneo.com.my/2017/11/09/kerajaan-negeri-diminta-bantu-angun-ppn

Hao, H., Li, X., \& Zhang, J. (2013), Impacts of part-time farming on agricultural Land use in ecologically vulnerable areas in North China. Journal of Resources and Ecology, 4(1):70-79. 2013. DOI: http://dx.doi.org/10.5814/j.issn.1674-764x.2013.01.010. http://citeseerx.ist.psu.edu/viewdoc/download?doi=10.1.1.972.6946\&ep=rep1\&typepdf https://jifpro.or.jp/bfpro/sn/sn-17/1522/

Hussin, S. H., Daud, A. I. A., \& Ashari, N. M. (2018). Preliminary Analysis of Adoption of Sago Smallholders Satellite Estate Development (SSSED) Programme among Sago Cultivators in Mukah/Dalat Areas of Sarawak, Malaysia. Global Business and Management Research, 10(2), 137-145. Retrieved from: https://search.proquest.com/openview/47ab18902d 36842d7fd8a4 4744141830/1?pqorigsite=gscholar\&cb l=696409.

Ishak, S. Z. A., Taibi, M., \& Yaakub, A. N. (2017). Impact of sago crop commercialization programs on gender roles of Melanau communities in Sarawak, Malaysia. Asian Social Science, 13(12), 35-44.doi.org/10.5539/ass.v13n12p35. Retrieved from: http://www.ccsenet.org/journal/ind ex.php /ass/article/download/70284/39426

Khulidin, K. A. (2015). Technology Transfer For Young Generation Entrepreneur Through MARDI Youth Agropreneur Programme. FFTC-MARDI International Seminar on Cultivating the Young Generation of Farmers with Farmland Policy Implications, May 25-29. Selangor. Retrieved from: http://ap.fftc.agnet.org/ap_db.php?id=446

Man, N. (2012). Unleashing youth potentials in developing the agricultural sector. Pertanika Journal of Social Sciences \& Humanities, 20 (1): $93-106$.

Ming, W. Y. T., \& Siong, C. C. (2014). Towards strengthening the development of women entrepreneurship in Malaysia. Gender in Management: An International Journal. Retrieved from https://www.emerald.com/insight/content/doi/10.1108/GM-10-20130122/full/html

Nag, A., Jha, S. K., Mohammad, A., \& Maiti, S. (2017). Measuring Attitude of Rural Youth towards Dairying as an Occupation: A Likert Scale. International Journal of Current Microbiology and Applied Sciences, 6(12), https://doi.org/10.20546/ijcmas.2017.612.371

Naim, H. M., Yaakub, A. N., \& Hamdan, D. A. A. (2016). Commercialization of sago throughestate plantation scheme in Sarawak: The Way Forward. International Journal of Agronomy, 2016. Retrieved from: https://doi.org/10.1155/2016/8319542

Najim, M. M. M., Lee, T. S., Haque, M. A., \& Esham, M. (2007). Sustainability of rice production: A Malaysian perspective. The Journal of Agricultural Sciences, 3(1). Retrieved from: https://www.academia.edu/2684991/SUSTAINABILITY_OF_RICEPRODUCTION_A_MALAYSIA N_PERSPECTIVE

participation among youths in Abia State, Nigeria. International Journal of Food and

Rakan Sarawak. (2006). Mukah Sedia Laksana Konsep Zon Pengeluaran. Suara Sarawak, p.3.

Retrieved from: https://sciencedocbox.com/78298736-Physics/Ke-r-a-j-a-a-n-n-e g-e-r-i-t-el-a-h.html

Sarawak Data. (2017). Sago starch 10 years performance. Retrieved from: https://data.sarawak.gov.my/home/data/resource/f00930cb-1fa0-450e-81463d1e814f122c

Shanjeevika, V., Indumathy, K., \& Murugan, P. P. (2018). Constraints Faced by the Rural Youth in Farm Activities. Journal of Extension, 30(3). doi.org/10.26725/JEE.2018.3.30.6137-6139. 
Simatupang, D. O., Dawapa, M., Fachrizal, R., \& Untari, U. (2019). Social and Economic Capital on Sustainability of Sago Processing Business. International Journal of Civil Engineering and Technology, 10(3). Retrieved from http://www.iaeme.com/ijciet/issues.asp?JType =IJCIET\& VType $=10 \&$ IType $=03$

Singh, S. P., \& Williamson, H. Jr. (1981). Part-Time Farming: Productivity And Some Implications Of Off-Farm Work By Farmers. Southern Journal Of Agricultural Economics. DOI: 10.22004/ag.econ. 30129

Suara Sarawak. (2019). 1343 Belia Diajar Bercucuk Tanam. Suara Sarawak, Ekonomi. Retrieved from https://suarasarawak.my/2019/05/04/1343-belia-diajar-bercucuk tanam787568/

Suara Sarawak. (2019). Industri rumbia berkembang. Suara Sarawak, Ekonomi. Retrieved from https://suarasarawak.my/2019/07/30/industri-rumbia-berkembang/

Taibi, M., Ishak, S. Z. A., \& Tuah, K. M. (2018). Melanau Women Engagement in Income Generating Activity of Sago Pearls-Based Food Products: Level of Participation and Motivation Factors. Global Business \& Management Research, 10(2), 96-105. Retrieved from: https://drive.google.com/file/d/1gDZI09YMyOSGTyZXjpHOGiRh9Z GBnRT4/view

Tiraieyari, N., \& Krauss, S. E. (2018). Predicting youth participation in urban agriculture in Malaysia: insights from the theory of planned behavior and the functional approach to volunteer motivation. Agriculture and Human Values, 35(3), 637-650. Retrieved from: https://link .springer.com/article/10.1007/s10460-018-9854-8

Toader, M., \& Roman, G. V. (2015). Family farming-examples for rural communities development. Agriculture and Agricultural Science Procedia, 6, 89-94. Retrieved from: https://doi.org/10.1016/j.aaspro.2015.08.043

Toyoda, Y. (2008). Anthropological Studies of Sago Palm in Papua New Guinea (No. 13). Tokyo: Rikkyo University Centre for Asian Area Studies. Retrieved from: https://rikkyo.repo.nii.ac.jp/?a ction=pages_view_main\&active_action=repository_viw_main_item_detail\&item_id=15055 \&item_no=1\&page_id=13\&block_id=49

Trendov, N. M., Varas, S., \& Meng, Z. (2019). Digital technologies in agriculture and rural areas: Status report. Organization of the United Nations, Rome. Retrieved from http://www.fao.org/3 /ca4985en/ca4985en.pdf

Trisia, M. A., Metaragakusuma, A. P., Osozawa, K., \& Bai, H. (2017). Do Small-Scale Farmers Want to Plant Sago Palm? An Empirical Analysis of the Factors Influencing Farmer Participation in Luwu Utara Regency, Indonesia. Journal of Agriculture and Crops, 3(12), 97-109. Retrieved from: https://ideas.repec.org/a/arp/jacarp/2017p97109.html

Uddin, M. R., Hoque, N., Ibrahim, M., \& Mamun, A. (2014). Work motivation: A Study on regular and part-time Employees of Bangladesh. Int. J. Manag. Bus. Res, 4(3), 235-245. Retrieved from: https://www.sid.ir/en/journal/ViewPaper.aspx?id=429095

Wardis, G. (2014). Socio-economic factors that have influenced the decline of sago consumption in small islands: a case in rural Maluku, Indonesia. South Pacific Studies, 34(2), 99-116. Retrieved from: http://cpi.kagoshimau.ac.jp/publicatio ns/southpacificstudies/sps/sps342/South\%20Pa

Yaakub, A. N., Naim, H. M., \& Hamdan, D. A. A. (2018). Challenges of Sustainable Livelihood among Small-scale Sago Farmers in Mukah District of Sarawak. Global Business \& Management Research, 10(2). Retrieved from: https://www.researchgate.net/public cation/329587577_ 